\title{
Retropharyngeal Lymph Node
}

National Cancer Institute

\section{Source}

National Cancer Institute. Retropharyngeal Lymph Node. NCI Thesaurus. Code C77649.

A lymph node located in the retropharyngeal space behind the upper part of the pharynx. 